\title{
Preanalytical Factors Affecting the Mean Platelet Volume: a Review
}

\author{
Katalin S Zsóri ${ }^{1,2}$, Judit M Mahalek ${ }^{3}$, Mohammad A Mokarrami ${ }^{4}$, Zoltán Csiki ${ }^{5}$ and \\ Amir H Shemirani ${ }^{2,6, *}$
}

${ }^{1}$ Central Pharmacy, Erzsébet Hospital, Sátoraljaújhely; ${ }^{2}$ LabPharm Kft, Sátoraljaújhely; ${ }^{3}$ Central Intensive Care Unit, Medical Center, Hungarian Defense Forces, Budapest; ${ }^{4}$ Department of Surgery, Bács-Kiskun Hospital, Kalocsa; ${ }^{5}$ Department of medicine, Debrecen university, Debrecen; ${ }^{6}$ MTA-DE Vascular Biology, Thrombosis and Hemostasis Research Group, Hungarian Academy of Sciences, Debrecen, Hungary

\begin{abstract}
Mean platelet volume (MPV) as an indicator of platelet activation is a subject of many studies. Since the introduction of automated hematology analyzers, many authors described mean platelet volume as a marker for different pathologic conditions. It is also known that numerous preanalytical conditions could affect MPV results. Specimens are usually tested several hours after blood collection. There are some specific hematology analyzers which are in use by the majority of hematology laboratories. This review demonstrates some important aspects related to MPV measurement in routine laboratory.
\end{abstract}

Keywords: Mean platelet volume, Preanalytical variables, Hematology analyzer, Anticoagulation, Blood.

\section{INTRODUCTION}

Mean platelet volume (MPV) has been discussed as an indicator of platelet function: larger platelets are more reactive and related to a shortened bleeding time. It is established that the platelet volume is correlated with platelet activation and function [1]. Small platelets have lower functional abilities than larger ones [2]. Changes of MPV values have been shown in different patient groups [3-5]. MPV is universally available, an easy test to perform and economic in routine laboratories. Besides these attractive properties, there are some drawbacks concerning MPV measurements. We try to review some of the preanalyticalvariabilities related to platelet volume enumeration.

\section{METHODS FOR MPV MEASUREMENT}

Different analyzers have been used for MPV measurement and every finding specifically deserves mention, because the method and type of instrumentation is one of the co-variables to influence the results. Platelet volume has been measured by three different techniques in routine laboratories [6]. The electrical impedance method is based on the Coulter principle. When a dilute suspension of cells pass through a small aperture, each cell briefly changes the resistance of the electrical current between two electrodes on both sides of the aperture. Electrical impedance is proportional to the volume of the particle traversing the aperture, and so this method

\footnotetext{
"Address correspondence to this author at the MTA-DE Vascular Biology, Thrombosis and Hemostasis Research Group, Hungarian Academy of Sciences, Debrecen, Hungary; Tel: +36306856608;

Fax: +3647525334; E-mail: shemirani1@gmail.com
}

can estimate cell sizing and counting. A major disadvantage of the impedance method is that cell size analysis cannot discriminate large platelets from other similarly sized particles, such as small or fragmented red cells [7].

In optical method, a diluted blood specimen passes through the sensing zone, which a beam of laser light is focused. Scattered light is detected at a specific angle (one-dimensional) or two specific angles (twodimensional), and converted to an electric impulse. The number of impulses generated is proportional to the number and volume of cells [8].

The third and new possibility to measure platelet count and platelet volume is optical fluorescence, which has been introduced recently on the Sysmexanalyzers. A polymethine dye is used in this technology to stain platelets and simultaneous counting of fluorescent platelets. The optical fluorescence count is more reliable at low platelet count and more appropriate for making clinical decisions, even for platelet transfusion [9].

It has been shown that for values in the normal range, three different methods demonstrated $20-25 \%$ variation in the measurement [6]. Another study calculated up to $40 \%$ difference between MPV measurements by impedance and optical methods [10].

\section{ANTICOAGULANTS}

Different anticoagulants and reagents is in use to minimize preanalytical activation in vitro, but most of them are hard to apply for routine laboratory because of impracticality [11]. It has been shown that standard 
phlebotomy does not activate platelets significantly with different anticoagulants [12]. Salts of EDTA (dipotassium or tripotassium EDTA, disodium EDTA) with around $1.5 \mathrm{mg} / \mathrm{ml}$ of blood generally used for routine hematology testing and $\mathrm{Na}_{3}$-citrate $(0.109 \mathrm{~mol} / \mathrm{l}$ or $0.129 \mathrm{~mol} / \mathrm{l})$ generally used for routine coagulation testing [13]. These anticoagulants have been used and studied for their roles in stabilization of platelet parameters [11, 14-24]. Thompson et al found $\mathrm{K}_{3}$ EDTA reliable anticoagulant for MPV evaluation after two hours of blood drowning, and Na-citrate proved as unreliable [14]. A different research group by using blood samples containing $\mathrm{K}_{3}$ EDTA or $\mathrm{Na}_{2}$ EDTA and impedance method demonstrated significant continuing to increase MPV over seven hours after phlebotomy [15]. Blood samples anticoagulated with citrate revealed the same trend. Macey et al showed platelet volume measured by $\mathrm{K}_{3}$ EDTA anticoagulated blood and optical method was reliable two hours postvenesection [11]. Another study by the impedance method revealed that both EDTA and citrate are reliable anticoagulants after one hour of sampling [16]. On the contrary, McShine et al observed a significant increase of MPV in $\mathrm{K}_{3} \mathrm{EDTA}$ samples and decreased in $\mathrm{Na}_{3}$ citrated samples by impedance method after one hour of blood incubation at ambient temperature, which became stable after approximately four hours [20]. The same pattern of results was also obtained using optical methods, however, higher MPV results were observed for EDTA samples.

Cord blood has been stored in EDTA at ambient temperature for four hours, and measured by impedance method presented no significant change of MPV results compare to time zero [17]. They demonstrated that MPV was significantly increased after 6 hours of venesection at room temperature and it was in accordance with markedly elevated CD62P as a marker of platelet activation. Lancé and co-workers concluded that best time to measure MPV from EDTA and sodium-citrate anticoagulated samples is 120 and 60 minutes after venipuncture, respectively [18]. DiazRicard et al. demonstrated that MPV in EDTA anticoagulated blood did not significantly increased compared to baseline during the first three hours of blood drawing by optical method [19]. They measured samples by impedance method and depicted a reference range for each anticoagulant.

$\mathrm{K}_{3}$ EDTA is recommended by the International Council for Standardization in Hematology as the anticoagulant of choice for complete blood count [25]. Several studies have been published on the stability of
MPV results against various conditions. Lance et al. demonstrated that platelets swell in the first two hours of phlebotomy in EDTA and in the first hour in citrate by impedance method [18]. They also concluded that platelet size stored in citrate is significantly smaller compared to those stored in EDTA. But some researches show MPV may be measured in sodium citrate with a better accuracy and reproducibility than in EDTA. Furthermore, such measurements are not influenced by incubation time, unlike for EDTA [22]. In blood collected in $\mathrm{K}_{3}$ EDTA, there was an increase in MPV in the first two hours, but sodium citrate proved unreliable for the measurement of MPV [14]. Trowbridge et al. found EDTA an unreliable anticoagulant to measure platelet volume [10]. On the contrary, Reardon et al showed MPV to be stabilized by sodium citrate and prostaglandin E1 together by the impedance method but not optical method [24]. In another study, MPV measured by fluorescent flow cytometry method and significantly increased in EDTA after three hours incubation at room temperature [26]. According to their results, false higher MPV can be overcome by sample storage at $4^{\circ} \mathrm{C}$.

\section{DISCUSSION AND CONCLUSION}

Pre-analytical variables, such as storage time and temperature, type of anticoagulant and methodology of measurement, affect the evaluation of MPV. Even different concentrations of a specific anticoagulant result in various platelet swelling [22]. Artificial platelet swelling and shape change after addition of anticoagulant to the sample is known for a while [27]. The effect of EDTA on platelet structure is not completely understood. However, it is partly explained by modifications of both the membranes lining the canalicular system and those forming the platelet cell wall by exposure of platelets to EDTA [28]. Besides, phosphorylation patterns of platelet proteins change by exposure to EDTA [19].

As an MPV increases over time by exposure to some anticoagulants, this elevation was shown to be proportional to the delay in time between blood sampling and laboratory analysis. For reliable MPV measurement, researchers must carefully control the possible influence of anticoagulant on the MPV, either standardizing the incubation time between phlebotomy and analysis or using an alternative anticoagulant or additive.

Platelet aggregation by any means causes incorrect MPV measurement. Although EDTA is used in the 
everyday hematological laboratory, it induces pseudothrombocytopenia [29], and heparin or citrate usage instead of EDTA did not overcome in vitro platelet aggregation [30]. Alternative anticoagulant has been suggested to inhibit pseudothrombocytopenia [20, 31-33].

Difference between results from different authors may come from a number of individuals included in the study, different method of comparison, or use of different physical principles to measure MPV. Neither impedance method, nor optical method takes into account the shape change of platelets [34]. As a result, these methods do not agree with each other.

In conclusion, until the standardization of MPV measurements for routine practical use, thorough description of MPV assessment is necessary i.e., technique, type and concentration of anticoagulant, storage time and temperature [35]. In this way, we may increase use of MPV as an effective diagnostic and prognostic factor in different pathologic disorders.

\section{ACKNOWLEDGEMENTS}

Grant sponsor was GOP-2.1.1-11/M-2013-2529 project.

\section{REFERENCES}

[1] Martin JF, Trowbridge EA, Salmon G, Plumb J. The biological significance of platelet volume: its relationship to bleeding time, platelet thromboxane B2 production and megakaryocyte nuclear DNA concentration. Thromb Res 1983; 32: 443-60. http://dx.doi.org/10.1016/0049-3848(83)90255-4

Thompson CB, Eaton KA, Princiotta SM, Rushin CA, Valeri CR. Size dependent platelet subpopulations: relationship of platelet volume to ultrastructure, enzymatic activity, and function. Br J Haematol 1982; 50: 509-19. http://dx.doi.org/10.1111/j.1365-2141.1982.tb01947.x

[3] Yavuz S, Ece A. Mean platelet volume as an indicator of disease activity in juvenile SLE. Clin Rheumatol 2014; 33: 637-41. http://dx.doi.org/10.1007/s10067-014-2540-3

[4] Ulutas KT, Dokuyucu R, Sefil F, Yengil E, Sumbul AT, Rizaoglu $\mathrm{H}$, et al. Evaluation of mean platelet volume in patients with type 2 diabetes mellitus and blood glucose regulation: a marker for atherosclerosis? Int J Clin Exp Med 2014; 7: 955-61.

[5] Sansanayudh N, Anothaisintawee T, Muntham D, McEvoy M, Attia J, Thakkinstian A. Mean platelet volume and coronary artery disease: a systematic review and meta-analysis. Int J Cardiol 2014; 175: 433-40. http://dx.doi.org/10.1016/j.ijcard.2014.06.028

[6] Latger-Cannard V, Hoarau M, Salignac S, Baumgart D, Nurden P, Lecompte T. Mean platelet volume: comparison of three analysers towards standardization of platelet morphological phenotype. Int J Lab Hematol 2012; 34: 30010. http://dx.doi.org/10.1111/j.1751-553X.2011.01396.x
[7] Michelson AD: Platelets, 3rd edn. London; Waltham, MA: Academic Press; 2013.

[8] Briggs C, Harrison P, Machin SJ. Continuing developments with the automated platelet count. Int J Lab Hematol 2007; 29: 77-91.

http://dx.doi.org/10.1111/j.1751-553X.2007.00909.x

[9] Briggs C, Harrison P, Grant D, Staves J, MacHin SJ. New quantitative parameters on a recently introduced automated blood cell counter--the XE 2100. Clin Lab Haematol 2000; 22: $345-50$ http://dx.doi.org/10.1046/j.1365-2257.2000.00330.x

[10] Trowbridge EA, Reardon DM, Hutchinson D, Pickering C. The routine measurement of platelet volume: a comparison of light-scattering and aperture-impedance technologies. Clin Phys Physiol Meas 1985; 6: 221-38. http://dx.doi.org/10.1088/0143-0815/6/3/003

[11] Macey M, Azam U, McCarthy D, Webb L, Chapman ES, Okrongly D, et al. Evaluation of the anticoagulants EDTA and citrate, theophylline, adenosine, and dipyridamole (CTAD) for assessing platelet activation on the ADVIA 120 hematology system. Clin Chem 2002; 48: 891-9.

[12] Schneider DJ, Tracy PB, Mann KG, Sobel BE. Differential effects of anticoagulants on the activation of platelets ex vivo. Circulation 1997; 96: 2877-83.

http://dx.doi.org/10.1161/01.CIR.96.9.2877

[13] Narayanan S. The preanalytic phase. An important component of laboratory medicine. Am J Clin Pathol 2000; 113: 429-52.

http://dx.doi.org/10.1309/CONM-Q7R0-LL2E-B3UY

[14] Thompson CB, Diaz DD, Quinn PG, Lapins M, Kurtz SR, Valeri CR. The role of anticoagulation in the measurement of platelet volumes. Am J Clin Pathol 1983; 80: 327-32.

[15] O'Malley T, Ludlam CA, Fox KA, Elton RA. Measurement of platelet volume using a variety of different anticoagulant and antiplatelet mixtures. Blood Coagul Fibrinolysis 1996; 7: 4316.

http://dx.doi.org/10.1097/00001721-199606000-00001

[16] Dastjerdi MS, Emami T, Najafian A, Amini M. Mean platelet volume measurement, EDTA or citrate? Hematology 2006 11: 317-9.

http://dx.doi.org/10.1080/10245330600954163

[17] Freise KJ, Schmidt RL, Gingerich EL, Veng-Pedersen $P$ Widness JA. The effect of anticoagulant, storage temperature and dilution on cord blood hematology parameters over time. Int J Lab Hematol 2009; 31: 496-504. http://dx.doi.org/10.1111/j.1751-553X.2008.01066.x

[18] Lance MD, van Oerle R, Henskens YM, Marcus MA. Do we need time adjusted mean platelet volume measurements? Lab Hematol 2010; 16: 28-31. http://dx.doi.org/10.1532/LH96.10011

[19] Diaz-Ricart M, Brunso L, Pino M, Navalon F, Jou JM, Heras $\mathrm{M}$, et al. Preanalytical treatment of EDTA-anticoagulated blood to ensure stabilization of the mean platelet volume and component measured with the ADVIA counters. Thromb Res 2010; 126: e30-5.

http://dx.doi.org/10.1016/j.thromres.2010.04.002

[20] McShine RL, Sibinga S, Brozovic B. Differences between the effects of EDTA and citrate anticoagulants on platelet count and mean platelet volume. Clin Lab Haematol 1990; 12: 27785 http://dx.doi.org/10.1111/j.1365-2257.1990.tb00038.x

[21] McShine RL, Das PC, Sibinga CT, Brozovic B. Effect of EDTA on platelet count and other platelet parameters in blood and blood components collected with CPDA-1. Vox Sang 1991; 61: 84-9. http://dx.doi.org/10.1111/j.1423-0410.1991.tb00251.x

[22] Bath PM. The routine measurement of platelet size using sodium citrate alone as the anticoagulant. Thromb Haemost 1993; 70: 687-90. 
[23] Hedberg P, Lehto T. Aging stability of complete blood count and white blood cell differential parameters analyzed by Abbott CELL-DYN Sapphire hematology analyzer. Int J Lab Hematol 2009; 31: 87-96. http://dx.doi.org/10.1111/j.1751-553X.2007.01009.x

[24] Reardon DM, Hutchinson D, Preston FE, Trowbridge EA. The routine measurement of platelet volume: a comparison of aperture-impedance and flow cytometric systems. Clin Lab Haematol 1985; 7: 251-7. http://dx.doi.org/10.1111/j.1365-2257.1985.tb00033.x

[25] Recommendations of the International Council for Standardization in Haematology for Ethylenediaminetetraacetic Acid Anticoagulation of Blood for Blood Cell Counting and Sizing. International Council for Standardization in Haematology: Expert Panel on Cytometry. Am J Clin Pathol 1993; 100: 371-2.

[26] Daves M, Zagler EM, Cemin R, Gnech F, Joos A, Platzgummer S, et al. Sample stability for complete blood cell count using the Sysmex XN haematological analyser. Blood Transfus 2015; 13: 576-82.

[27] White JG. Effects of ethylenediamine tetracetic acid (EDTA) on platelet structure. Scand J Haematol 1968; 5: 241-54. http://dx.doi.org/10.1111/j.1600-0609.1968.tb01743.x

[28] Gachet C, Hanau D, Spehner D, Brisson C, Garaud JC, Schmitt DA, et al. Alpha Ilb beta 3 integrin dissociation induced by EDTA results in morphological changes of the platelet surface-connected canalicular system with differential location of the two separate subunits. J Cell Biol 1993; 120: 1021-30.

http://dx.doi.org/10.1083/jcb.120.4.1021
[29] Shreiner DP, Bell WR. Pseudothrombocytopenia: manifestation of a new type of platelet agglutinin. Blood 1973; 42: 541-9.

[30] Schrezenmeier H, Muller H, Gunsilius E, Heimpel H, Seifried E. Anticoagulant-induced pseudothrombocytopenia and pseudoleucocytosis. Thromb Haemost 1995; 73: 506-13.

[31] Schuff-Werner P, Steiner M, Fenger S, Gross HJ, Bierlich A, Dreissiger $\mathrm{K}$, et al. Effective estimation of correct platelet counts in pseudothrombocytopenia using an alternative anticoagulant based on magnesium salt. $\mathrm{Br} J$ Haematol 2013; 162: 684-92. http://dx.doi.org/10.1111/bjh.12443

[32] Manthorpe R, Kofod B, Wiik A, Saxtrup O, Svehag SE. Pseudothrombocytopenia. In vitro studies on the underlying mechanism. Scand J Haematol 1981; 26: 385-92. http://dx.doi.org/10.1111/j.1600-0609.1981.tb01679.x

[33] Savage RA. Pseudoleukocytosis due to EDTA-induced platelet clumping. Am J Clin Pathol 1984; 81: 317-22.

[34] Kolesnikova IV, Potapov SV, Yurkin MA, Hoekstra AG, Maltsev VP, Semyanov KA. Determination of volume, shape and refractive index of individual blood platelets. J Quant Spectrosc Radiat Transf 2006; 102: 37-45. http://dx.doi.org/10.1016/j.jqsrt.2006.02.050

[35] Lance MD. Mean platelet volume needs standardisation. Comment on Asher et al. Thromb Haemost 2014; 112: 137141. Thromb Haemost 2015; 113: 908. http://dx.doi.org/10.1160/TH14-07-0590

\footnotetext{
Received on 08-12-2015

Accepted on 30-12-2015

Published on 20-01-2016

http://dx.doi.org/10.15379/2408-9877.2016.03.01.05

(c) 2016 Zsóri et al.; Licensee Cosmos Scholars Publishing House.

This is an open access article licensed under the terms of the Creative Commons Attribution Non-Commercial License (http://creativecommons.org/licenses/by-nc/3.0/), which permits unrestricted, non-commercial use, distribution and reproduction in any medium, provided the work is properly cited.
} 